УДК 615.014.21:615.453.6:615.32

DOI https://doi.org/10.11603/2312-0967.2018.4.9690

\title{
TECHNOLOGICAL ASPECTS OF TABLETS CREATION BASED ON FLAMMULINA VELUTIPES BIOMASS DRY POWDER
}

\author{
(C) T. A. Butkevych ${ }^{1}$, M. L. Syatynya ${ }^{1}$,V. P. Popovych ${ }^{2}$ \\ Bohomolets National Medical University ${ }^{1}$, Kyiv \\ «PTF «Acme» Co. Ltd², Ukrainka \\ e-mail:but-t@ukr.net
}

\begin{abstract}
The aim of the work. To study the pharmaco-technological properties of granulate and tablets based on Flammulina velutipes biomass dry powder, to develop the composition and technology of the medication.

Materials and Methods. Research of granules and tablets pharmaco-technological properties (sieve analysis, bulk density, tapped density, compressibility index, Hausner ratio, flowability of tablet mass, average weight, resistance to crushing, friability and disintegration of tablets) was carried out in accordance to the requirements of State Pharmacopoeia of Ukraine 2nd edition.

Results and Discussion. The determined pharmaco-technological parameters of the granulate indicate good values of the bulk density, tapped density, compressibility index, Hausner ratio and flowability. An intermediate product undergoes a tabletting process to produce a qualitative finished product of satisfactory appearance (plain, cylindrical tablets with a facet, yellowish-white color with brown inclusions, with a height of $4 \mathrm{~mm}$, and diameter of $10 \mathrm{~mm}$ ), a constant average mass $(1.0 \mathrm{~g})$, and strength $(68 \mathrm{~N})$.

Conclusions. The pharmaco-technological properties of tablet mass (granulate) and Flammulina velutipes biomass dry powder tablets (sieve analysis, bulk density, tapped density, compressibility index, Hausner ratio, flowability, average weight, resistance to crushing, friability and disintegration) were studied. The composition and technology of Flammulina velutipes biomass dry powder tablets have been developed, pharmaco-technological parameters of their quality have been studied, technological block diagram of industrial production has been developed.
\end{abstract}

Key words: Flammulina velutipes, tablets, pharmaco-technological properties.

Introduction. Nowadays in Ukraine the interest in the usage of medicinal plants and medical mushrooms, as well as the medications received on their basis, is quite high. It is due to the fact that when properly dosed, they are practically non-toxic, harmless, relatively affordable, effective and, in some cases, do not have competitors in complex action [1]. Large resources, availability of raw materials, and the possibility of cultivation make raw materials of natural origin to be a promising object of research in order to develop new medications [2].

On the previous stages of the study, the influence of four groups of excipients on the pharmaco-technological characteristics of Flammulina (F.) velutipes biomass dry powder (BDP) tablets was studied. The optimal representatives of the studied groups of excipients were selected for obtaining the medication by the method of wet granulation [3].

The aim of the work was to develop the composition and technology of $F$. velutipes BDP tablets.

\section{Materials and Methods}

The objects of the study were tablet mass (granulate) and $F$. velutipes BDP tablets, obtained by the method of wet granulation.

All researches were conducted on the basis of Scientific and Production Association "Ekomed" and at the department of Pharmaceutical and industrial drug technology of O. Bohomolets National Medical University.

Sieve analysis was determined by granulate sifting through SLM-200 sieve No. 1400, 355, 180, 125, and weighing each fraction to an accuracy of $0.01 \mathrm{~g}$. The study of bulk density and tapped density was carried out on the device of "Promprylad" Interval-NO. The compressibility index and Hausner ratio were calculated according to the formula. Flowability of the granulate was determined using a vibration device TK-1TRP 02-M Universal with a diameter of the outlet of the funnel $15 \mathrm{~mm}$. The flow properties of the granulate were determined according to the scale of State Pharmacopoeia of Ukraine 2nd edition [5].

Tablets were compressed on a Single Punch Tablet Press TDP-5 (MINHUA Pharmaceutical Machinery CO., Ltd., China). Resistance to crushing was determined using a YPJ-200A Tablet hardness tester, friability was studied using Tablet friability tester CS-2, disintegration was determined with Disintegration Tester BJ-2 (MINHUA Pharmaceutical Machinery CO., Ltd., China).

Results and Discussion. According to the results of previous studies, excipients for the preparation of $F$. velutipes BDP tablets were selected and the following composition of the intermediate product - tablet mass (Table 1) was proposed.

ISSN 2312-0967. Фармацевтичний часопис. 2018. № 4 
Dry components were weighed on technical scales, sieved on sieve and placed in intermediate storage containers. The solution of binder was prepared as follows: 2.0 potato starch was ground with $6-10 \mathrm{ml}$ of purified water and added to $100 \mathrm{ml}$ of boiling purified water, mixed up until homogeneous liquid was formed. F. velutipes BDP, powdered sugar and white clay were loaded into a laboratory granulator with a $3 \mathrm{~mm}$ hole size of the sieve, than a solution of binder was added. The resulting mass was dried and passed through a sieve with a $1 \mathrm{~mm}$ hole size in special equipment, powdered with stearic acid and given for a further study after sifting through a sieve system (Table 2) [5].

As can be seen from the data in Table 2, the fractional composition of the granulate is heterogeneous, but the medium particles fraction content in the size of 0.5 $1.0 \mathrm{~mm}$ (76.26\%) predominate. The content of the smallest particles fraction (smaller than $0.25 \mathrm{~mm}$ ) is $4.03 \%$. The obtained results indicate the possibility of tablets obtaining with a constant average mass based on composition of the intermediate product.
Фармацевтична технологія, біофармація, гомеопатія Pharmaceutical technology, biopharmacy, homeopathy

The determined pharmaco-technological parameters of the tablet mass (granulate) indicate good values of the bulk density, tapped density, compressibility index, Hausner ratio and flowability (Table 3). Data were studied immediately after obtaining and after 7 days of storage in hermetically sealed containers (labeled with appropriate labels).

The results indicate that this intermediate product has pharmaco-technological parameters that do not significantly change during storage, so it can be tableted to produce a qualitative finished product - tablets based on F. velutipes BDP.

The good value of the flowability is important for the rapid and continuous feeding of the tablet mass to the press tool and the uniform filling of the matrix volume, determines the productivity of the pressing process. The obtained results allow us to proceed to the development of tablet technology and to study pharmaco-technological parameters of obtained tablets (Table 4).

The technological block diagram of tablets based on F. velutipes BDP production has been developed and proposed (Figure 1). The technological process of

Table 1. The composition of the tablet mass for creation of a medication based on F. velutipes BDP

\begin{tabular}{|c|l|c|}
\hline No & \multicolumn{1}{|c|}{ Substances } & Content, $\%$ \\
\hline 1 & F. velutipes BDP & 80 \\
\hline 2 & Powdered sugar & 15 \\
\hline 3 & White clay & 1 \\
\hline 4 & Stearic acid & 1 \\
\hline 5 & $2 \%$ starch paste & 3 \\
\hline Total: & & 100 \\
\hline
\end{tabular}

Table 2. The results of sieve analysis of tablet mass (granulate) for creation of a medication based on F. velutipes BDP

\begin{tabular}{|c|c|c|}
\hline $\begin{array}{c}\text { Mass of } \\
\text { sample, } g\end{array}$ & Results & Content, \% \\
\hline \multirow{3}{*}{100,00} & Did not pass through the sieve No 1400 & 1,31 \\
\cline { 2 - 3 } & Did not pass through the sieve No 355 & 8,55 \\
\cline { 2 - 3 } & Did not pass through the sieve No 180 & 76,26 \\
\cline { 2 - 3 } & Did not pass through the sieve No 125 & 9,85 \\
\hline
\end{tabular}

Table 3. Pharmaco-technological parameters of the tablet mass (granulate) for creation of a medication based on $F$. velutipes BDP

\begin{tabular}{|c|l|c|c|}
\hline No & \multicolumn{1}{|c|}{ Characteristic } & $\begin{array}{c}\text { Tablet mass (granulate) } \\
\text { (after obtaining) }\end{array}$ & $\begin{array}{c}\text { Tablet mass (granulate) } \\
\text { (after 7 days of storage) }\end{array}$ \\
\hline 1 & Bulk density, $\mathrm{P}(\mathrm{g} / \mathrm{ml})$ & $0,437 \pm 0,003$ & $0,436 \pm 0,001$ \\
\hline 2 & Tapped density, $\mathrm{P}_{\text {tapped }}(\mathrm{g} / \mathrm{ml})$ & $0,491 \pm 0,009$ & $0,494 \pm 0,003$ \\
\hline 3 & Compressibility index, $(\%)$ & $11,01 \pm 1,50$ & $11,85 \pm 0,43$ \\
\hline 4 & Hausner ratio & $1,13 \pm 0,02$ & $1,14 \pm 0,01$ \\
\hline 5 & Flowability, $\mathrm{V}_{n}(\mathrm{~g} / \mathrm{sec})$ & $3,60 \pm 0,24$ & $3,70 \pm 0,16$ \\
\hline
\end{tabular}

Note: $\mathrm{n}=5$.

Table 4. Pharmaco-technological parameters of the tablets based on F. velutipes BDP

\begin{tabular}{|c|l|c|}
\hline No & \multicolumn{1}{|c|}{ Characteristic } & Tablets based on Flammulina velutipes biomass dry powder \\
\hline 1 & Average weight, $\mathrm{g}$ & $1,011 \pm 0,010$ \\
\hline 2 & Resistance to crushing, $\mathrm{N}$ & $67,60 \pm 3,36$ \\
\hline 3 & Friability, $\%$ & $0,36 \pm 0,17$ \\
\hline 4 & Disintegration, min & $12,78 \pm 0,43$ \\
\hline
\end{tabular}

Note: $\mathrm{n}=5$.

ISSN 2312-0967. Pharmaceutical review. 2018. № 4 
Фармацевтична технологія, біофармація, гомеопатія

Pharmaceutical technology, biopharmacy, homeopathy

Raw material

Intermediate products and materials

Tools for the disinfection of
processing facilities and
equipment, staff

\section{Stage 1. Preparation of production}

Stage 2. Preparation of raw materials and components

The control of the production process

Microbiological purity of air, rooms, equipment, staff

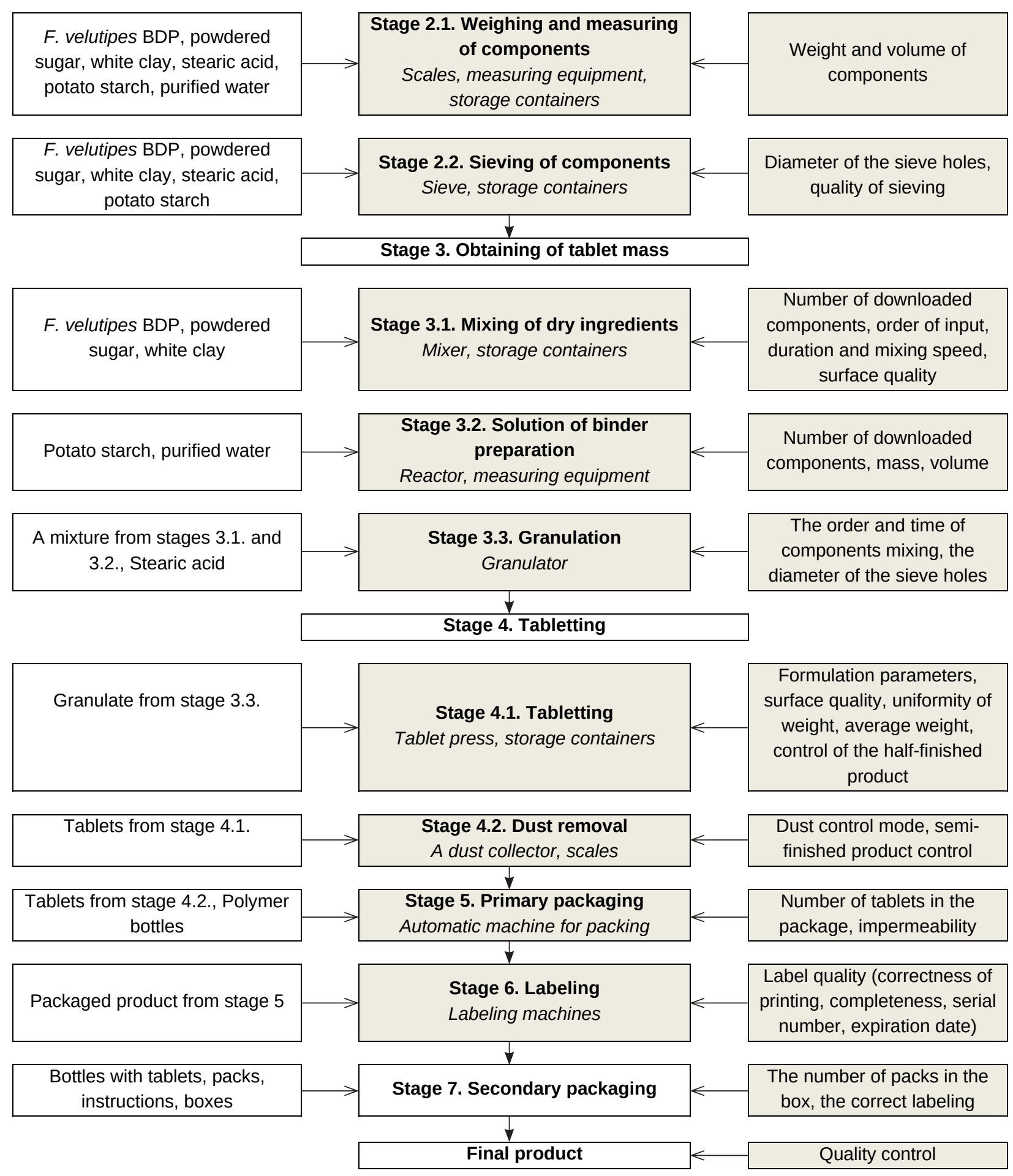

Figure 1. The technological block diagram of tablets based on F. velutipes BDP production

ISSN 2312-0967. Фармацевтичний часопис. 2018. № 4 
tablets obtaining consists of 7 main stages: preparation of production, preparation of raw materials and components, obtaining of tablet mass, tabletting, primary packaging, labeling, secondary packaging.

Thus, the addition of excipients and the usage of the wet granulation process can produce an intermediate product (tablet mass), which has good parameters of the pharmaco-technological characteristics, does not change them during storage (within 7 days) and undergoes a tabletting process to produce a qualitative finished product of satisfactory appearance (plain, cylindrical tablets with a facet, yellowish-white color with brown inclusions, with a height of $4 \mathrm{~mm}$, and diameter
Фармацевтична технологія, біофармація, гомеопатія Pharmaceutical technology, biopharmacy, homeopathy of $10 \mathrm{~mm})$, a constant average mass (1.0 g), and strength $(68 \mathrm{~N})$.

Conclusions. 1. The pharmaco-technological properties of tablet mass (granulate) and Flammulina velutipes biomass dry powder tablets (sieve analysis, bulk density, tapped density, compressibility index, Hausner ratio, flowability, average weight, resistance to crushing, friability and disintegration) were studied. 2. The composition and technology of Flammulina velutipes biomass dry powder tablets have been developed, pharmaco-technological parameters of their quality have been studied, technological block diagram of industrial production has been developed.

\title{
ТЕХНОЛОГІЧН АСПЕКТИ СТВОРЕННЯ ТАБЛЕТОК НА ОСНОВІ СУХОГО ПОРОШКУ БІОМАСИ FLAMMULINA VELUTIPES
}

\author{
Т. А. Буткевич ${ }^{1}$, М. Л. Сятиня ${ }^{1}$, В. П. Попович ${ }^{2}$ \\ Національний медичний університет імені О.О. Богомольця, ${ }^{1}$ Київ \\ TOВ «ВТФ «ЕКМІ»², Українка \\ e-mail: but-t@ukr.net
}

Мета роботи. Вивчити фрармако-технологічні властивості грануляту та таблеток на основі сухого порошку біомаси (СПБ) Flammulina velutipes, розробити склад та технологію засобу.

Матеріали і методи. Дослідження фрармако-технологічних властивостей грануляту та таблеток (ситовий аналіз, насипна густина, насипна густина після усадки, показник стисливості, коефіцієнт Гауснера, сипкість таблеткової маси, середня маса, стійкість до роздавлювання, стираність та розпадання таблеток) проводили відповідно до вимог Держаної фрармакопеї України 2 видання.

Результати й обговорення. Визначені фрармако-технологічні параметри грануляту свідчать про хороші значення насипної густини, насипної густини після усадки, показника стисливості, коефіцієнта Гауснера та сипкості. Проміжний продукт піддається процесу таблетування 3 одержанням якісного готового продукту із задовільним зовнішнім виглядом (плоскоциліндричні таблетки з фраскою, жовтувато-білого кольору із коричневими вкрапленнями, висотою 4 мм, діаметром 10 мм), сталою середньою масою (1,0 г) та міцністю (68 N).

Висновки. Досліджено фрармако-технологічні властивості таблеткової маси (грануляту) та таблеток CпБ F. velutipes (ситовий аналіз, насипна густина, насипна густина після усадки, показник стисливості, коефіцієнт Гауснера, сипкість, однорідність маси, стійкість до роздавлювання, стираність та розпадання). Розроблено склад та технологію таблеток на основі СПБ F. velutipes, вивчено фрармако-технологічні показники їх якості, розроблено технологічну блок-схему промислового виробництва.

Ключові слова: Flammulina velutipes; таблетки; фрармако-технологічні властивості.

\section{ТЕХНОЛОГИЧЕСКИЕ АСПЕКТЫ СОЗДАНИЯ ТАБЛЕТОК НА ОСНОВЕ СУХОГО ПОРОШКА БИОМАССЫ FLAMMULINA VELUTIPES}

\author{
Т. А. Буткевич ${ }^{1}$ М. Л. Сятыня ${ }^{1}$, В. П. Попович ${ }^{2}$ \\ Национальный медицинский университет имени А. А. Богомольца ${ }^{1}$, Киев \\ ООО «ПТФ «ЭКМИ»², Украинка \\ e-mail: but-t@ukr.net
}

Цель работы. Изучить фрармако-технологические свойства гранулята и таблеток на основе сухого порошка биомассы (СПБ) Flammulina velutipes, разработать состав и технологию средства.

Материалы и методы. Исследование фрармако-технологических свойств гранулята и таблеток (ситовой анализ, насыпная плотность, насыпная плотность после усадки, показатель сжимаемости, коэффициент Гауснера,

ISSN 2312-0967. Pharmaceutical review. 2018. № 4 
Фармацевтична технологія, біофармація, гомеопатія Pharmaceutical technology, biopharmacy, homeopathy

сыпучесть таблеточной массы, средняя масса, устойчивость к раздавливанию, истираемость и распадаемость таблеток) проводили в соответствии с требованиями ГФУ 2 издание.

Результаты и обсуждение. Определены фрармако-технологическиепараметры гранулята, которые свидетельствуют о хороших значениях насыпной плотности, насыпной плотности после усадки, показателя сжимаемости, коэффрициента Гауснера и сыпучести. Промежуточный продукт подвергается процессу таблетирования сполучением качественного готового продукта удовлетворительного внешнего вида (плоскоцилиндрические таблетки с фраской, желтовато-белого цвета с коричневыми вкраплениями, высотой 4 мм, диаметром 10 мм), постоянной средней массой (1,0 г) и прочностью (68 N).

Выводы. Исследованы фрармако-технологические свойства таблеточной массы (гранулята) и таблеток СПБ F. velutipes (ситовой анализ, насыпная плотность, насыпная плотность после усадки, показатель сжимаемости, коэффрициент Гауснера, сыпучесть, средняя масса, устойчивость к раздавливанию, истираемость и распадаемость). Разработан состав и технология таблеток на основе СПБ F. velutipes, изучены фрармако-технологические показатели качества, разработана технологическая блок-схема их промышленного производства.

Ключевые слова: Flammulina velutipes; таблетки; фрармако-технологические свойства.

\section{Список літератури}

1. Шостак Т. А. Особливості фрармацевтичної розробки рослинних препаратів (огляд літератури) / Т. А. Шостак, Т. Г. Калинюк, Н.І.Гудзь // Фітотерапія. Часопис. - № 4. - 2014. - C. 77-82.

2. Вишневська Л. І. Технологічні дослідження лікарської рослинної сировини та її композицій у створенні нових препаратів / Л. І. Вишневська // Вісн. фрармац. - 2008. № 4. - С. 33-38.

3. Буткевич Т. А. Вивчення впливу допоміжних речовин на фрармако-технологічні властивості таблеток сухого порошку біомаси Flammulina velutipes / Т. А. Буткевич,
М. Л. Сятиня, В. П. Попович // Фармацевт. часоп. - № 3. - 2017. - С. 47-51.

4. Державна Фармакопея України: в 3 т. / Державне підприємство «Український науковий фрармакопейний центр якості лікарських засобів». - 2-е вид. - Харків : Державне підприємство «Український науковий фрармакопейний центр якості лікарських засобів», 2015. - Т. 1. - 1128 с.

5. Вибір раціональних допоміжних речовин для створення таблеток «Ангіолін» методом вологої грануляції / О. С. Бідненко, Л. І. Кучеренко, І. А. Мазур [та ін.] // Фармацевт. часоп. - № 2. - 2016. - С. 16-21.

\section{References}

1. Shostak TA, Kalyniuk TH, Hutz NI. [Aspects of pharmaceutical development of herbal medicines (Literary review)]. Fitoterapia. chasop. 2014;4: 77-82. Ukrainian.

2. Vyshnevska LI. [Technological investigation in the medicinal plant raw material and its compositions in creating new medicines]. Visn. Pharm. 2008;4: 33-8. Ukrainian.

3. Butkevych TA, Siatynia ML, Popovych VP. [Study of the excipients influence on pharmaco-technological properties of Flammulina velutipes biomass dry powder tablets]. Farmatsevt. chasop. 2017;3: 47-51. Ukrainian.

4. State Pharmacopoeia of Ukraine: in 3 vol. [Державна Фармакопея України: в 3 т.]State Enterprise "Ukrainian Research Center expert pharmacopoeia quality medicines." 2nd ed. Kharkiv State Enterprise "Ukrainian Research Center expert pharmacopoeia drug quality," 2015. Ukrainian.

5. Bidnenko OS, Kucherenko LI, Mazur IA, Moriak ZB. [Choice of rational excipients to create Angiolin" tablets by wet granualtion]. Farmatsevt chasop. 2016;2: 16-21. Ukrainian. 